NBER WORKING PAPER SERIES

\title{
CROSS-STATE VARIATION IN HEALTH CARE UTILIZATION OF SSDI BENEFICIARIES: EVIDENCE FROM MEDICARE CLAIMS
}

\author{
Joyce Manchester \\ Working Paper 24759 \\ http://www.nber.org/papers/w24759 \\ NATIONAL BUREAU OF ECONOMIC RESEARCH \\ 1050 Massachusetts Avenue \\ Cambridge, MA 02138 \\ June 2018
}

Yonatan Ben-Shalom, Catherine Benham, Bard Hill, Stephen Klein, Mary Kate Mohlman, Jason Seligman, Jonathan Skinner, David Stapleton, and David Weaver provided helpful comments on earlier drafts. I thank Stephanie Tomlin and Steve Houston at the Dartmouth Atlas of Health Care Project for their patient technical assistance with the data. Chloe Wexler provided invaluable research assistance. This research was supported by the U.S. Social Security Administration through grant \#1 DRC12000002-05 to the National Bureau of Economic Research as part of the SSA Disability Research Consortium. The findings and conclusions expressed are solely those of the author(s) and do not represent the views of SSA, any agency of the Federal Government, the Vermont Legislative Joint Fiscal Office, or the NBER.

NBER working papers are circulated for discussion and comment purposes. They have not been peer-reviewed or been subject to the review by the NBER Board of Directors that accompanies official NBER publications.

(C) 2018 by Joyce Manchester. All rights reserved. Short sections of text, not to exceed two paragraphs, may be quoted without explicit permission provided that full credit, including (C) notice, is given to the source. 
Cross-State Variation in Health Care Utilization of SSDI Beneficiaries: Evidence from Medicare Claims

Joyce Manchester

NBER Working Paper No. 24759

June 2018

JEL No. I1,I13,I18

\begin{abstract}
Using 100 percent Medicare Part B fee-for-service (FFS) claims in 2012 for people under age 65, I examine office and outpatient services by state and primary diagnosis for the service. The number of services per Medicare-eligible beneficiary in the U.S. Social Security Disability Insurance (SSDI) program was about 32 in 2012, or 2.7 per month, comparable to services for the $65+$ Medicare population. The number of services for SSDI beneficiaries ranged from almost 48 per capita in Minnesota to 23 in Arkansas. Services for musculoskeletal impairments averaged 4.6 per capita, ranging from 6.7 in Minnesota to 2.5 in Hawaii. The greatest variation occurred in services for mental disorders, averaging 3.2 for the U.S. but ranging from 9.1 in Massachusetts to 1.4 in Alabama. Factors such as the number of health care professionals or hospital beds per capita, the share enrolled in Medicare Advantage, and demographic factors are associated with health care utilization across states. Knowledge of health care utilization could inform policy choices for programs such as early intervention efforts both at the federal level and tailored to particular needs at the state level.
\end{abstract}

Joyce Manchester

Vermont Legislative Joint Fiscal Office

One Baldwin Street

Montpelier, VT 05633

jmanchester@leg.state.vt.us 


\section{$\underline{\text { I. Introduction }}$}

About 10.6 million people in the United States received benefits from the Social Security Disability Insurance (SSDI) Program at the end of 2016, having qualified based on previous work history as well as serious disabilities that prohibit them from being able to work. Some policy makers would like to implement more effective policies to help people before their needs become so serious that they stop working and apply for SSDI, but little is known about how best to help them. All SSDI beneficiaries who have been on the program for at least 24 months are eligible for Medicare, however, suggesting that Medicare claims could be a rich source of information about the kinds of care used once on the program. Data on health care services by state and primary diagnosis offer insights into the health care challenges faced by SSDI beneficiaries in different parts of the country. Those same data provide a window into how health care differs for SSDI beneficiaries in different states.

Growth in the SSDI program since the 1980s has been greater than expected based on changes in the characteristics of the labor force during this period (Autor and Duggan 2003; Liebman 2015). The latest report on the SSDI Trust Fund suggests it will likely be exhausted by 2032 (Old Age, Survivors, and Disability Insurance Trustees, 2018). Consequently, proposals to reduce the number of workers coming into the SSDI program, known as early intervention, have caught the attention of policy makers (for example, Autor and Duggan 2010; Burkhauser and Daly 2012). Those developments have also raised interest in return-to-work programs to encourage SSDI beneficiaries to more actively explore possibilities for labor force participation, perhaps eventually leading to exiting the SSDI program. ${ }^{1}$ Knowing more about the health care used by the SSDI beneficiary population in each state could help policy makers target the needs of potential applicants as well as current beneficiaries.

Data from the Social Security Administration show the primary diagnoses at the time of eligibility for SSDI (see Figure 1), but this paper will show that they do not reflect the types of health care actually used. Among all SSDI beneficiaries in 2010, more than one-third had

\footnotetext{
${ }^{1}$ Some SSDI beneficiaries currently leave the program to return to work. Liu and Stapleton (2011) found that 10 years after their entry into the SSDI program, 28 percent of beneficiaries entering in 1996 had returned to work, 6.5 percent had their benefits suspended for work in at least one month, and 3.7 percent had their benefits terminated for work. The corresponding percentages are much higher for those who were younger than age 40 when entering the SSDI program.
} 
qualified on the basis of mental disorders and about one-quarter on the basis of disorders of the musculoskeletal system and connective tissue. ${ }^{2}$ Disorders of the nervous system and sense organs or circulatory system, injuries, and disorders of the endocrine, nutritional, and metabolic systems accounted for another quarter of beneficiaries. Using Medicare Part B claims data reveals that actual services for health care occur in a more diffuse pattern. Moreover, variation across states in the kinds of health care used is surprisingly large in some cases.

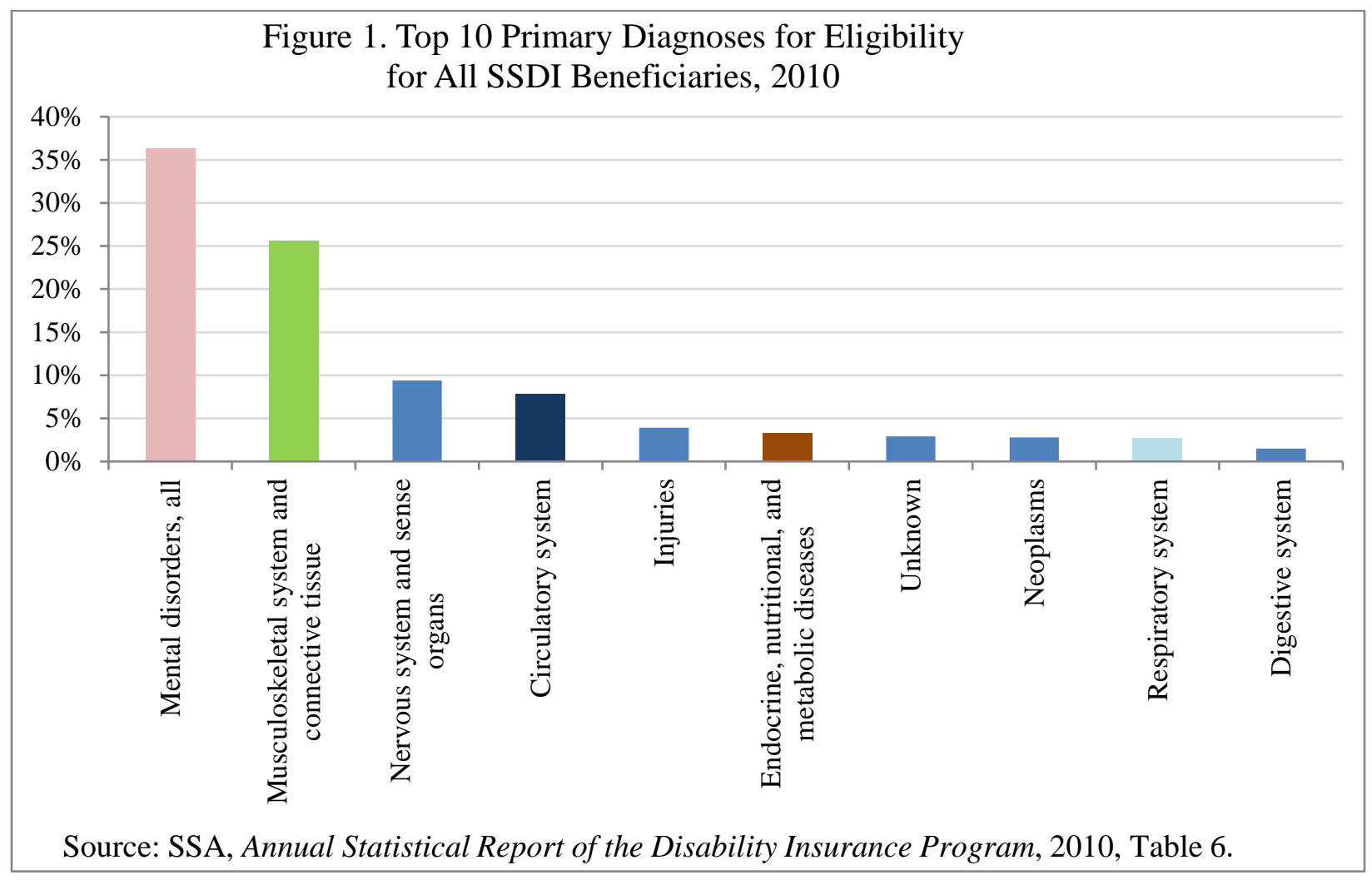

The focus of this paper is on office and outpatient services by primary diagnosis and state. I use the Medicare population under age 65 to avoid conflating health care services for age 65 seniors who are newly eligible for Medicare with services for age 65 SSDI beneficiaries. Using 100 percent fee-for-service Medicare claims for the population under age 65 in 2012, I can report a per capita measure of services for SSDI beneficiaries because they account for more than 99 percent of all Medicare Part B enrollees under age 65. Per capita office and

\footnotetext{
${ }^{2}$ The population of Medicare enrollees under age 65 in 2012 consisted almost entirely of SSDI beneficiaries as of 2010, as SSDI beneficiaries must be enrolled for 24 months before they qualify for Medicare. Among SSDI beneficiaries in 2010, fewer than 9 percent are likely to have died between 2010 and 2012 (Zayatz 2015).
} 
outpatient services by primary diagnosis for the visit form the basis of comparisons of health care used across states. Across the country, the top reason for office and outpatient services is musculoskeletal conditions (14 percent), followed by mental disorders (10 percent), circulatory conditions (9 percent), endocrine conditions (8 percent), and genitourinary conditions (7 percent) (see Figure 2). The divergence between primary diagnosis at time of eligibility and primary diagnosis for health care utilization is apparent. Mental disorders is the primary diagnosis at the time of eligibility for 36 percent of beneficiaries, but mental disorder services account for only 10 percent of the office and outpatient services, on average; musculoskeletal conditions is the primary diagnosis at the time of eligibility for 26 percent of beneficiaries, but musculoskeletal services account for only 14 percent of services. $^{3}$

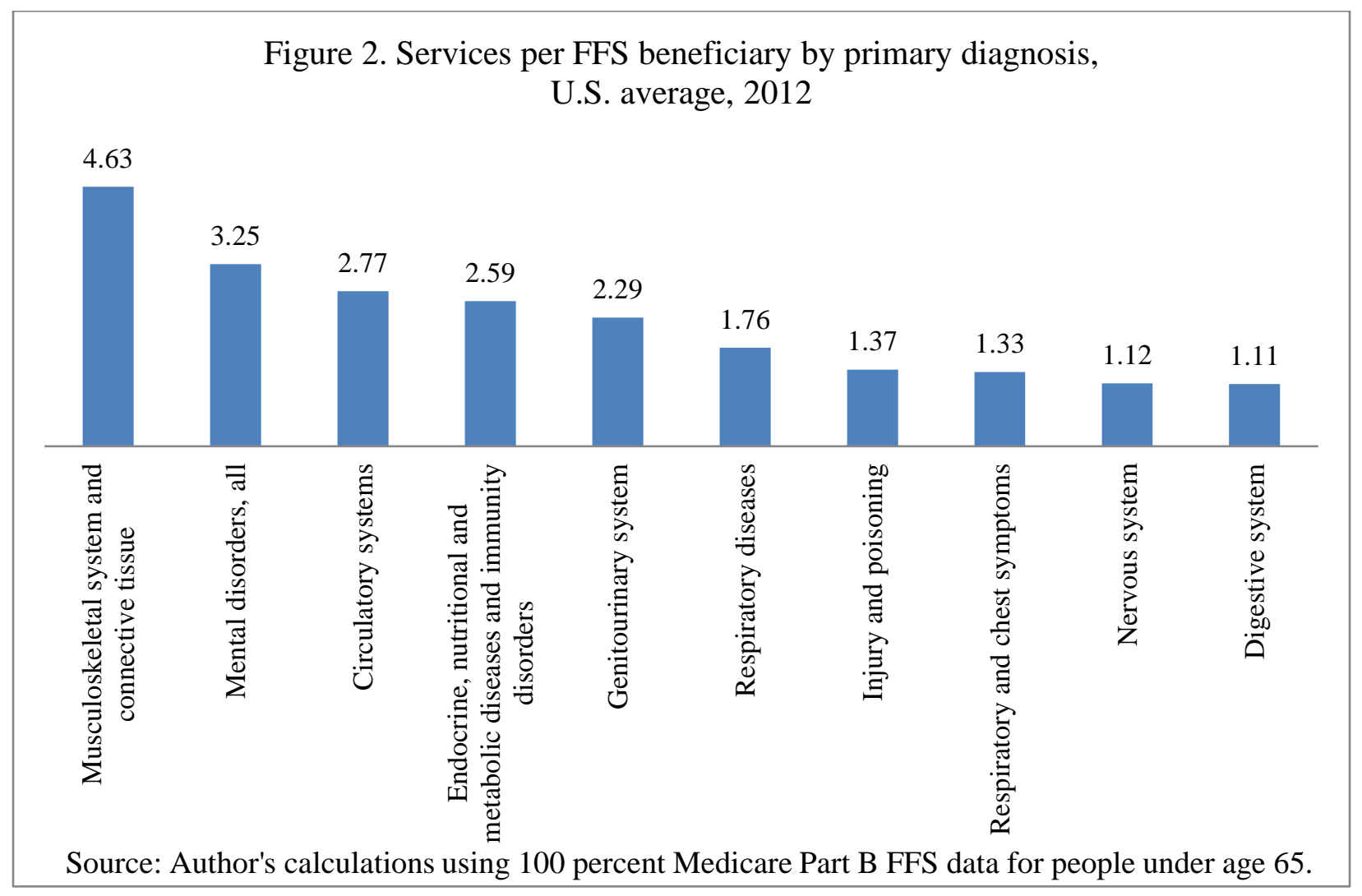

Those averages hide a great deal of variation in health care used by SSDI beneficiaries in different states. That variation could arise because the health needs and demographics of the

\footnotetext{
${ }^{3}$ Weathers, et al. (2010) described services used by SSDI beneficiaries in the Accelerated Benefits Demonstration in 2006 that provided beneficiaries with a health benefits package before the completion of the Medicare waiting period. At a high level, the services used appear comparable to those reported here.
} 
SSDI population vary across states. Cross-state variation in SSDI enrollment by age group was the subject of an earlier paper (Manchester and Tweed, 2015). It showed that the New England states have higher proportions of young people on the SSDI program than most other states, and that eligibility based on mental disorders was especially high in those states. Questions raised by those findings suggested that investigating the types of health care used across states could help our understanding of characteristics of the SSDI population.

Knowing the health care needs of the SSDI populations could alert policy makers to possible types of interventions to help SSDI beneficiaries reenter the workforce or to help potential SSDI beneficiaries avoid enrolling in the SSDI program in the first place.

Of course, the number and types of health care services observed reflect not only the needs of the SSDI population in each state but also the patterns of treatment for various diagnoses that could vary geographically. Protocols for treating back pain could differ significantly across states, ranging from using drugs alone to relying primarily on pain management intervention, requiring more or fewer services. Similarly, using medication-assisted therapy, an approach that combines behavioral therapy and medications rather than using drugs alone to treat substance abuse, may be more common in some parts of the country than others, again leading to differences in the observed number of services.

Much previous literature points to differences across geographic areas in both the demand for health care as measured by characteristics of the population and the supply of health care. The Dartmouth Atlas project has spotlighted geographic variation in health care spending using Medicare claims data for people age 65 and over to examine issues ranging from possible inefficiencies in the health care system to the care of chronic illness in the last two years of life (Dartmouth Atlas 2017). Finkelstein, Gentzkow, and Williams (2014) suggested that demandside factors such as health status, preferences and socioeconomic factors account for approximately half of the geographic variation in spending. The relatively low income of SSDI beneficiaries prior to eligibility for the program may place even more emphasis on individual characteristics in influencing health care needs. ${ }^{4}$ In a recent paper looking at longevity rather than health care per se, Chetty and Cutler (2016) found that geographic differences in life

\footnotetext{
${ }^{4}$ For evidence of relatively low earnings levels prior to participating in the SSDI program, see von Wachter, Song, and Manchester (2011), Figure 4.
} 
expectancy for individuals in the lowest income quartile were significantly correlated with health behaviors such as smoking, but they were not significantly correlated with access to medical care, physical environmental factors, income inequality, or labor market conditions. A recent paper by Cutler, Skinner, Stern and Wennberg (2017) using “strategic” survey questions, however, finds a greater role for physician beliefs in explaining variation in Medicare spending across regions. ${ }^{5}$ Similarities in physician beliefs within regions may arise through network models or local norms.

Recognizing the interplay of supply and demand factors that determines who is seen for what diagnosis, the results here represent a first look at state variation in health care used by the SSDI population through Medicare Part B. A number of limitations pertain to the picture of health care utilization that emerges. The absence of data on the secondary or tertiary reason for the service and on the cost of care leaves a big hole, ${ }^{6}$ as does the inability to track health care services of individual SSDI beneficiaries according to their primary diagnosis for eligibility. Services reported here do not include health care outside of fee-for-service Medicare Part B. I have no information on prescription drugs covered by Medicare Part D or on the medical or mental services of SSDI beneficiaries under age 65 who receive health care through Medicare Advantage, Part C. Some SSDI beneficiaries are eligible as well for the Supplemental Security Income (SSI) program, meaning that they are also eligible for Medicaid, but I have no data on health care provided through Medicaid alone. In addition, data on hospital stays for SSDI beneficiaries are not incorporated into the analysis. Nevertheless, the variation in frequency of services for different diagnosis types in office and

\footnotetext{
${ }^{5}$ Strategic surveys are used to estimate underlying preference parameters such as risk aversion; Cutler, et al., use detailed, scenario-based questions to ask physicians about their financial and practice organization as well as vignette-based questions about how the physician would manage elderly individuals with specific chronic health conditions and a given medical and treatment history.

${ }^{6}$ One of the earliest analyses of Medicare utilization by SSDI beneficiaries looked at Medicare reimbursements for a 1-in-20 sample of the 1972 cohort of newly eligible beneficiaries under age 62 for years 1974 to 1981 (Bye, Riley and Lubitz, 1987). The study found that 82 percent of the 1972 cohort continued to receive SSDI benefits for two years or more and became eligible for Medicare. The highest spending (including hospital costs) occurred for beneficiaries with genitourinary diagnoses (largely ESRD cases). Women's reimbursements were about 40 percent greater than men's, and the average reimbursement rate at that time dropped as age increased. About 70 percent of the beneficiaries were men. At that time, the largest diagnostic groups were circulatory (28 percent), musculoskeletal (15 percent), mental disorders (9 percent), and neoplasms (8 percent).
} 
outpatient services points to differing needs of the SSDI population and perhaps differences in supports offered that could affect early intervention or, in some cases, return to work.

The prominence of opioid addiction suggests that health care services for substance abuse are an important aspect of health care to track across states. Moreover, growing opioid addiction could have implications for disability insurance programs and the types of health care sought by disability insurance beneficiaries. Cutler, Meara, and Stewart (2017) found that areas with more rapid increases in opioid shipments have greater increases in Disability Insurance enrollment. In addition, the share of disability insurance beneficiaries who receive high doses of opioid drugs varies widely across states.

The desire to include health care services for substance abuse dictates the year for which data are examined in this paper. Starting in 2013, Medicare data on services related to substance abuse were redacted from various data sets to protect confidentiality. Data from 2012 are not affected by the redaction and provide the basis for analysis here. ${ }^{7}$

\section{Data and Methodology}

Analysis of health care utilization by Disability Insurance beneficiaries across states in this paper rests on fee-for-service Medicare claims data for people under age 65. Medicare claims data for people under age 65 overwhelmingly represent health care used by Disability Insurance beneficiaries, as only 0.7 percent of Medicare enrollees under age 65 are eligible for other reasons. Non-DI Medicare enrollees under age 65 fall into one of three groups. Patients with end-stage renal disease who are not receiving SSDI benefits ( 0.20 percent) and children under age 19 (0.03 percent) account for 0.23 percent of the non-DI Medicare enrollees (see Table 1). In addition, Railroad Retirement Board beneficiaries with disabilities are approximately 0.45 percent. In 2007, about 84,000 Railroad Retirement Board beneficiaries were disability beneficiaries or occupational disability beneficiaries, about half of whom were eligible for Medicare. $^{8}$

\footnotetext{
${ }^{7}$ Data on substance abuse services in other years will be restored at some future date.

${ }^{8}$ See Whitman (2008). Medicare coverage is available for disabled employee annuitants under age 65 who have been entitled to monthly benefits based on total disability for at least 24 months and to annuitants entitled to monthly benefits based on an occupational disability 30 months after being granted a disability freeze based on standards similar to those for total disability. See Railroad Retirement Board (2017).
} 
Table 1. Medicare Beneficiaries Under Age 65 in 2012

\begin{tabular}{ccccc}
\hline & Total & $\begin{array}{c}\text { SSDI } \\
\text { w/out ESRD }\end{array}$ & $\begin{array}{c}\text { SSDI } \\
\text { with ESRD }\end{array}$ & $\begin{array}{c}\text { ESRD } \\
\text { Only }\end{array}$ \\
\hline Under 65 Years & $8,624,192$ & $8,382,541$ & 224,301 & 17,350 \\
Share of All $<65$ & & $97.2 \%$ & $2.6 \%$ & $0.2 \%$ \\
& & & & \\
Under 19 Years & 2,531 & 215 & 2,145 & 171 \\
$\quad \begin{array}{l}\text { Share of All }<65 \\
\text { Share of }<19\end{array}$ & $0.03 \%$ & & & \\
\hline
\end{tabular}

Source: Based on Medicare \& Medicaid Statistical Supplement, Research Review/ 2013 Statistical Supplement, Table 2.3

SSDI beneficiaries who have been on the program for at least 24 months are eligible for Medicare Part A (hospital insurance) and Medicare Part B (office and outpatient services). In addition, SSDI beneficiaries with amyotrophic lateral sclerosis (ALS or Lou Gehrig's disease) are automatically enrolled in Medicare Part A in the first month they receive Social Security disability benefits. Medicare Part A is available at no charge, but enrollees must pay the premium for Part B services if they choose to enroll. Medicare enrollees with Parts A and B can join a Medicare Advantage (MA) plan. In 2012, 27 percent of Medicare beneficiaries under age 65 in the U.S. were enrolled in Medicare Advantage (Part C) compared with 31 percent of Medicare beneficiaries age 65 or above (Cubanski, et al., 2016). There was considerable variation in shares of Medicare enrollees in MA across states (see Appendix Figure A1). I focus on fee-for-service (FFS) services and enrollees because health care services for MA enrollees are not reported. In the analysis below, fee-for-service services in each state divided by the number of fee-for-service Medicare enrollees under age 65 in each state produces services per SSDI beneficiary enrolled in fee-for-service Medicare Part B.

The Dartmouth Institute for Health Policy and Clinical Practice provided files for fee-for-service Part B enrollees under age 65 from the Dartmouth Atlas of Health Care Project. ${ }^{9}$ The data show the total counts of services for office and outpatient services by ICD-9 diagnosis code and state of patient residence in 2012, 2013, and 2014. I received two files for each of the 50 states plus the District of Columbia. One set of files reports the number of office services by primary

${ }^{9}$ The Dartmouth Atlas Project is supported by SYNERGY, the Clinical and Translational Science Award (CTSA) Center at Dartmouth, funded by the National Institutes of Health. 
diagnosis code for care provided by physicians, laboratories, and other health care providers. The other set of files reports the number of outpatient services by primary diagnosis code.

The number of services for diagnosis codes related to substance abuse is redacted in the 2013 and 2014 files, as was required by federal law, leading to my focus on $2012 .{ }^{10}$ I have aggregated the 3-digit ICD-9 codes into the major diagnosis types used by the Social Security Administration for SSDI eligibility. ${ }^{11}$ All Dartmouth Atlas regional data reflect the experience of Medicare patients living in the region, regardless of where the care was actually delivered.

To protect the confidentiality of the data, the exact number of services in a state for a particular ICD-9 code is not reported when the number of services for that diagnosis code is less than 15 but greater than zero. The total number of services per state for each of the two provider types is known, however. I have inserted the average number of unreported services into each of those diagnosis types with missing data. The average number of unreported office services is about 7 , and the average number of unreported outpatient services is about 6.9. Total unreported services make up no more than 0.46 percent of total office services in any state in 2012 (Wyoming) and no more than 2.39 percent of total outpatient services (Hawaii).

The ICD-9 code V13 appears frequently in a few states but does not convey information about the specific purpose of the service. The V13 code means "personal and family history of other diseases” and represents less than 1 percent of office services on average across the United States in 2012. As of 2015, CMS no longer allowed the use of the code because it conveys so little information. In a few states, however, it was used frequently in 2012: Vermont (28 percent of all services), Michigan (8 percent), Rhode Island (6 percent) and Maine (6 percent). Cursory inspection of other types of services for those four states relative to the national averages suggests that some medical providers used the V13 code for follow-

\footnotetext{
${ }^{10}$ Under the previous regulations, the Center for Medicare and Medicaid Services (CMS) was required to redact all substance use disorder claims from the Research Identifiable Files (RIFs). At some point in the future, data on those services will become available again. On January 17, 2017, the Substance Abuse and Mental Health Services Administration (SAMHSA) finalized changes to the Confidentiality of Alcohol and Drug Abuse Patient Records Regulations, 42 CFR Part 2. Under those changes to the Part 2 regulations, CMS is now permitted to include substance use disorder claims data in the Research Identifiable Files (RIFs). Research Identifiable Files shipped or extracted after 05/22/2017 are no longer subject to the redaction.

11 The statistics group at the Social Security Administration provided the crosswalk between SSDI eligibility types and the ICD-9 codes. Note that one 4-digit ICD-9 code does not fit neatly into the SSA eligibility types. The code 3195 is included in SSA's “intellectual disability disorders” in the 3-digit classification but technically should fall under "other mental disability disorders.”
} 
up treatment such as physical therapy or aftercare. I have not allocated those V13 services to any particular diagnosis, but results by diagnosis for those four states should be viewed with caution.

To compare utilization of health care by SSDI beneficiaries across states, I use a "per capita” measure of office and outpatient services. The number of office and outpatient fee-for-service services overall or for specific diagnosis groups is the numerator, and the number of fee-forservice Medicare beneficiaries under age 65 on Part B in each state is the denominator. The Centers for Medicare \& Medicaid Services (CMS) reports the number of people under age 65 enrolled in Medicare Part B and Medicare Advantage by state in 2013. ${ }^{12}$ To obtain the number of enrollees in the United States for 2012, I multiply by the ratio of SSDI beneficiaries in June 2012 to SSDI beneficiaries in June 2013, or 0.9806, to find 7,699,557 Medicare Part B enrollees for all of the United States in 2012. I then subtract Part B beneficiaries who are enrolled in Medicare Advantage to find 5,693,992 fee-for-service enrollees. I apply the same method to enrollees in each state. California has 7.2 percent of all fee-for-service Part B enrollees under age 65 in 2012, for example, and Wyoming has just 0.2 percent.

Most beneficiaries from the SSDI beneficiary population in 2010 would have survived to be eligible for Medicare benefits in 2012. Based on experience from 2006 to 2010, about 5.6 percent of male SSDI beneficiaries died in the first year following entitlement, and about 3.8 percent died in the second year following entitlement. ${ }^{13}$ The percentages are slightly smaller for women. The probability of death drops to about 3 percent for men and about 2 percent for women after 2 or 3 years on the program before rising slightly as duration increases. On average, beneficiaries with musculoskeletal and mental disorders exhibit lower mortality than most other diagnostic groups, whereas beneficiaries with circulatory disorders have among the highest mortality rates.

After presenting results on office and outpatient services per capita for the 50 states and Washington D.C. for all diagnoses and the five most prevalent diagnoses, I also identify factors

\footnotetext{
${ }^{12}$ CMS, Office of Enterprise Data and Analytics, CMS Chronic Conditions Data Warehouse. MDCR Enroll AB 7, Total Medicare Enrollment: Part A and/or Part B Total, Aged, and Disabled Enrollees, by Area of Residence, Calendar Year 2013. Data for 2012 were not readily available.

${ }^{13}$ See Zayatz (2015), Table 13.
} 
associated with state variation using regression analysis. Explanatory variables include factors on the demand side and the supply side as well as some socioeconomic characteristics of populations.

\section{$\underline{\text { IV. Results }}$}

\section{$\underline{\text { A. Cross-State Variation in Office and Outpatient Services }}$}

In addition to looking at all office and outpatient services, I focus on services with primary diagnosis in five major groups that account for about half of all services nationwide: diseases and symptoms related to the musculoskeletal system and connective tissue; mental disorders; diseases and symptoms related to the respiratory system; diseases and symptoms related to the circulatory system; and endocrine, nutritional and metabolic diseases and immunity disorders. All Services. The total number of services provided by offices of physicians and other health care providers in 2012 among the FFS Part B Medicare population under age 65 (hereafter, SSDI beneficiaries) was 149.3 million. Divided among the 5.7 million people under age 65 who had FFS Part B coverage in 2012 (over 99 percent of whom were SSDI beneficiaries), the number of office services per capita was 26.2. In addition, there were 34 million outpatient services, or 6.0 per capita. For most purposes in this paper, I consolidate office and outpatient services because many services can be provided at either location. Summing office services and outpatient services leads to 32.2 services per capita in 2012, or about 2.7 services per month. Per enrollee, both the number of Medicare services and spending are similar for enrollees under age 65 and age 65 or older, according to $\mathrm{CMS} .^{14}$

At the state level, total office and outpatient services per capita ranged from 48.2 services per year in Minnesota to 23.4 services per capita in Arkansas (see Figure 3). The New England states are highlighted in various colors in many figures because they often tend to be among the states with higher numbers of services per capita. The United States average appears red. All of the New England states except New Hampshire are in the top ten states for total services per capita. They are joined by Minnesota, Michigan, Ohio, New York, and Wisconsin. The three states with the lowest number of services per capita are Arkansas, Arizona, and Wyoming.

\footnotetext{
${ }^{14}$ https://www.cms.gov/Research-Statistics-Data-and-Systems/Statistics-Trends-andReports/CMSProgramStatistics/2015/Downloads/UTIL/2015_CPS_MDCR_PHYSSUPP_1.pdf
} 


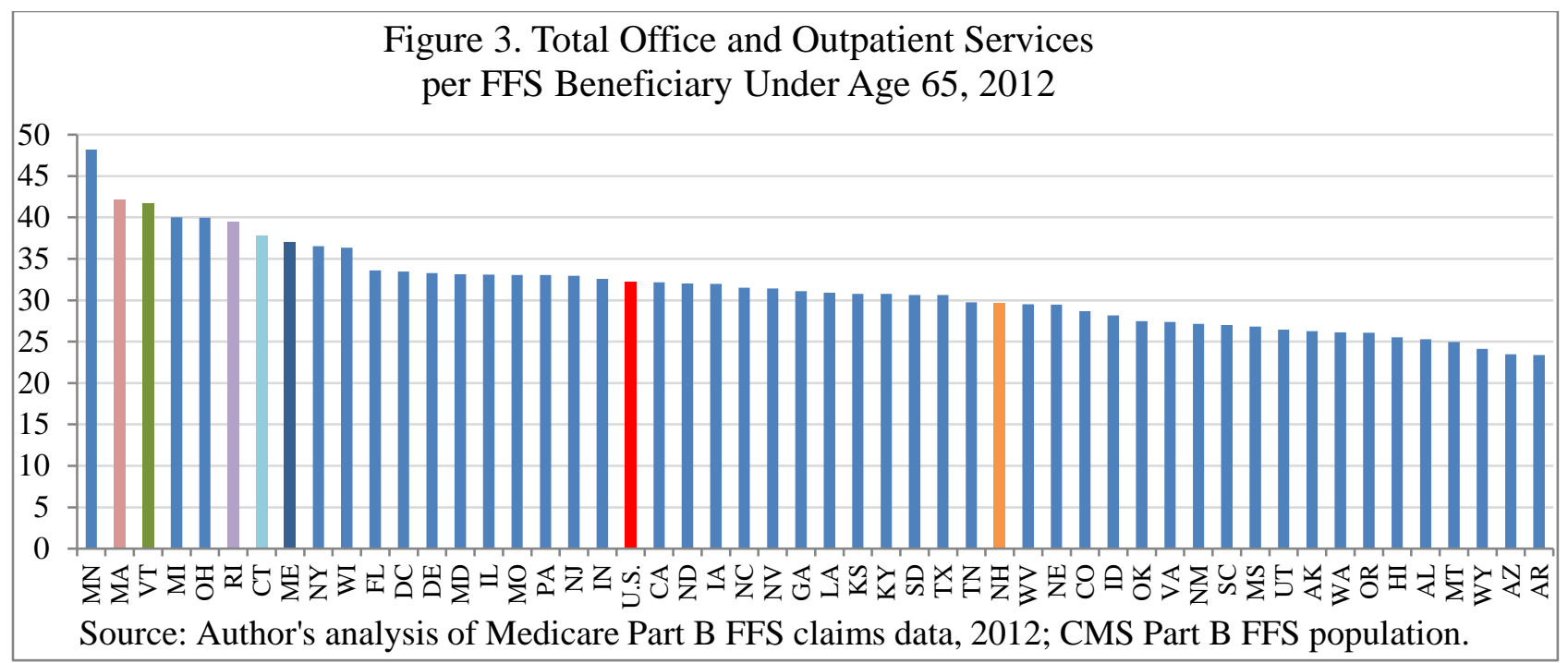

Musculoskeletal services. Services for diseases and symptoms of the musculoskeletal system and connective tissue comprise 14 percent of all office and outpatient services in the U.S., the largest share of services for a major diagnosis group. That result is not too surprising given that musculoskeletal conditions are the second most common reason for SSDI eligibility. The U.S. average number of services per capita for musculoskeletal diagnoses was 4.6 in 2012. The highest number of services occurred in Minnesota at 6.7 services per capita, and the lowest number of services occurred in Hawaii at 2.5 services per capita. Of the New England states, only Maine and Massachusetts are in the top ten states; New Hampshire, Vermont, and Connecticut fall below the national average. Hawaii, Oregon, and Arizona are the states with the lowest number of services per capita. 


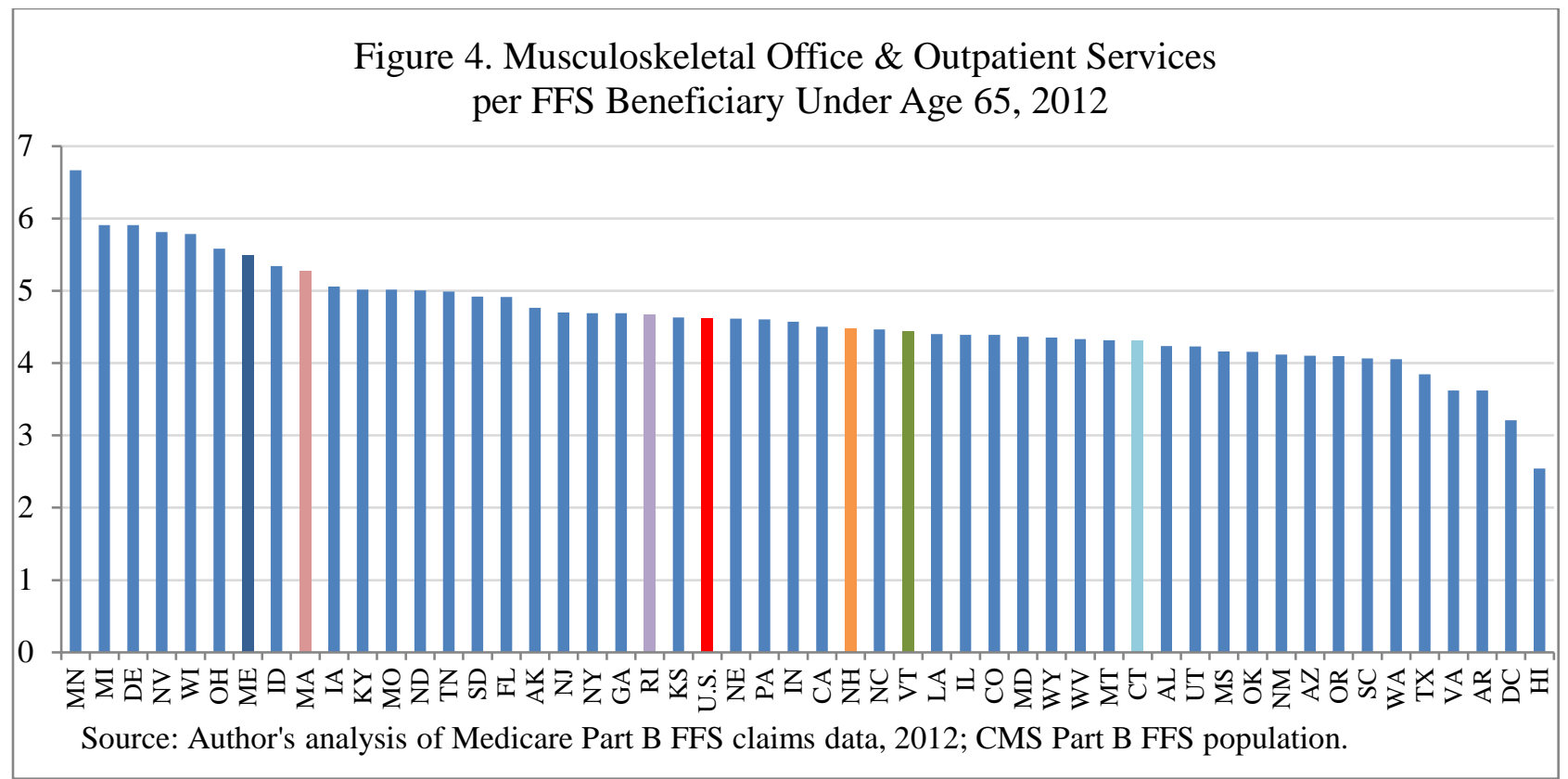

Mental disorders services. Across the U.S. as a whole, office and outpatient services for mental disorder diagnoses and symptoms occurred 3.2 times per capita in 2012, the largest major diagnosis category. Among the major diagnosis groups, the largest variation in services per capita across states occurs in services for mental disorders. Relative to the population of all FFS Part B enrollees under age 65 in each state, per capita services for mental disorders ranged from 9.1 services per year in Massachusetts to 1.4 service per year in Alabama (see Figure 5). All the New England states are in the top ten states. Alabama, Mississippi and Arizona are the states with the smallest number of services per capita for mental disorder diagnoses. 


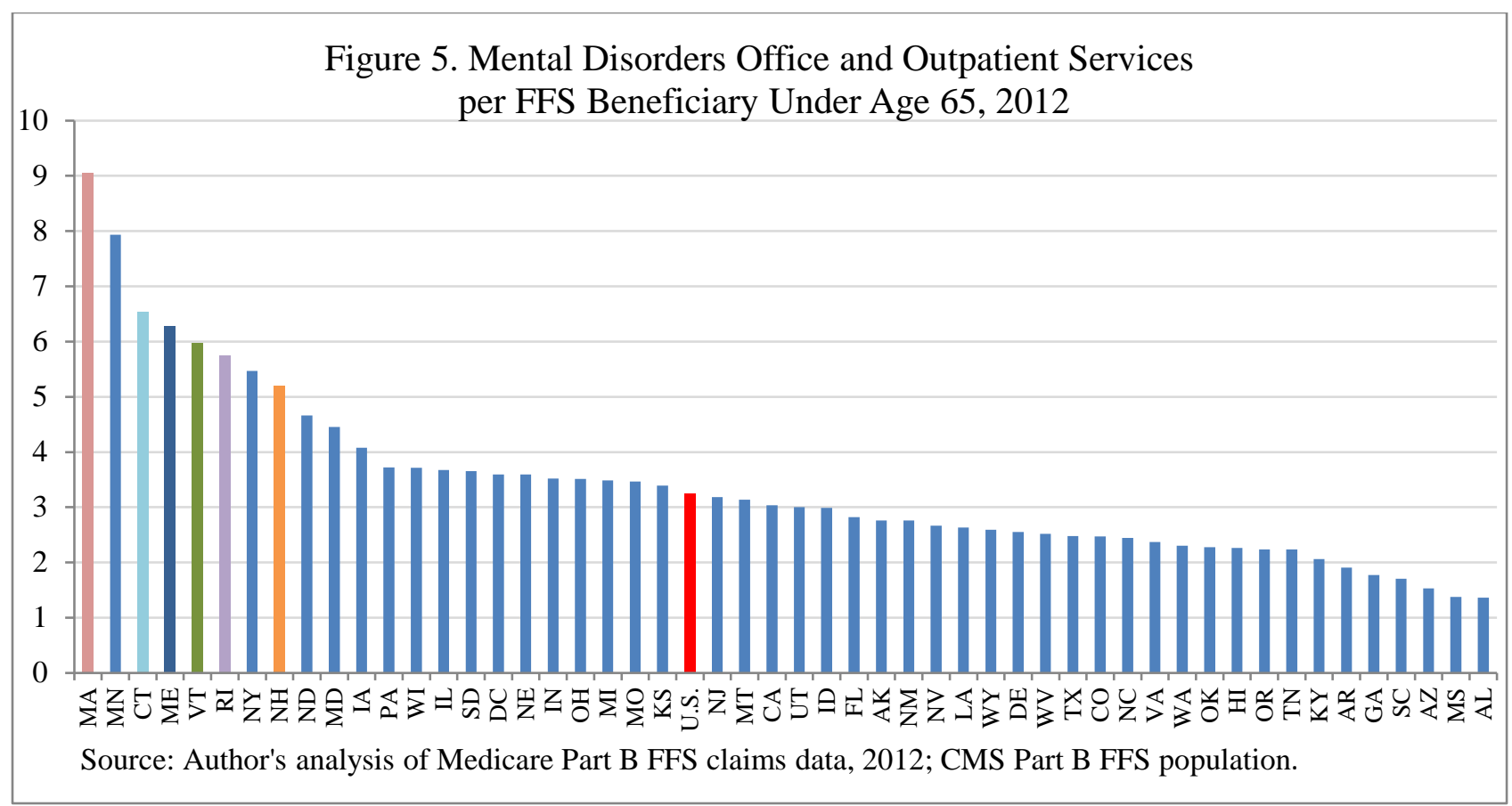

To explore more deeply the types of mental disorder diagnoses that lead to office and outpatient services, I looked at the services in the top eight states for three mental disorder diagnosis types that account for 95 percent of all mental disorder services: mood disorders (43 percent of all mental disorder services; includes depression), schizophrenic and other psychotic disorders (27 percent), and "other mental disorders" (25 percent; includes alcohol or drug dependence or psychoses, anxiety or personality disorders, sleep disorders, and post-traumatic stress disorder). All of the New England states are in the top eight states for per capita services in those categories and have at least 60 percent more services per capita on average than the U.S. for all mental disorder diagnoses together (see Figure 6). They also have substantially more services per capita for mood disorders and other mental disorders. Massachusetts and Minnesota stand out in services per capita for all mental disorders and mood disorders. Massachusetts and Vermont stand out in services per capita for other mental disorders. 


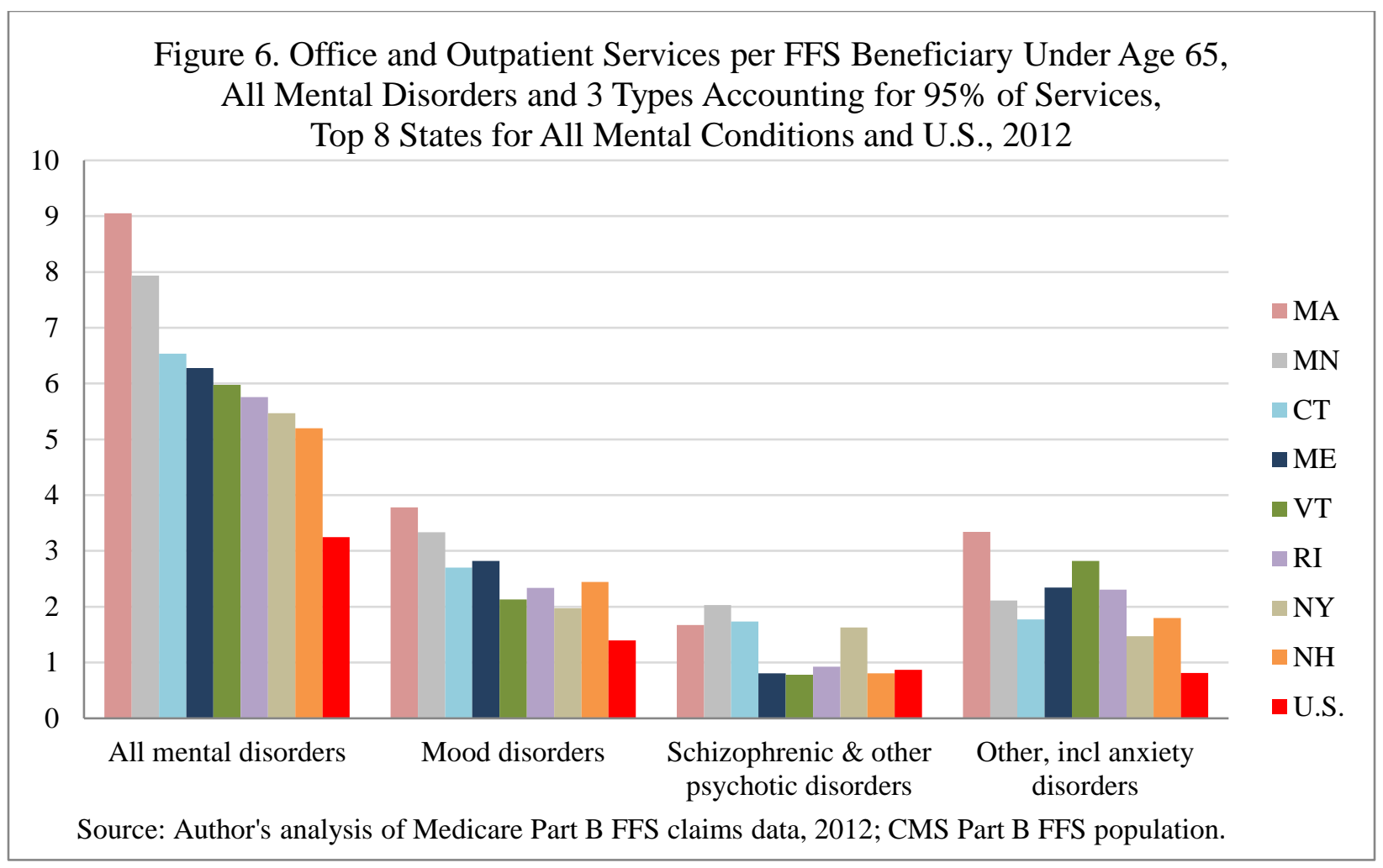

Services per capita among SSDI FFS beneficiaries reflect two elements: the share of SSDI beneficiaries who have services for a particular diagnosis, and the intensity of treatment for patients with that diagnosis. One indicator of the number of SSDI beneficiaries who are most likely to receive treatment for mood disorders, for example, is the share of beneficiaries with mood disorders as the reason for eligibility for the program. Data for 2010 show the six New England states among the top eight states with the highest shares of beneficiaries who had become eligible on the basis of mood disorders (see Appendix Table A1). For example, 22.6 percent of all SSDI beneficiaries in Massachusetts in 2010 had become eligible on the basis of mood disorders; the national average was 14.3 percent. Five of the six New England states are the top five states for the share of beneficiaries who became eligible on the basis of other mental disorders such as anxiety. In New Hampshire, 10.4 percent of all beneficiaries had become eligible on the basis of other mental disorders; the national average, and the share in Connecticut, was 3.8 percent.

Evidence for all Medicare FFS beneficiaries corroborates the SSDI prevalence of depression. In 2015, depression was added to the list of chronic conditions tracked by CMS among all Medicare 
FFS beneficiaries by state (CMS 2017). CMS reports the share of all Medicare beneficiaries who have at least one service with depression as the primary diagnosis. In 2015, Maine, Rhode Island, and Massachusetts had the highest prevalence rates for depression among all the states, followed by West Virginia, Kentucky, Missouri, and Minnesota. Further exploration of factors associated with the varying number of services per capita can be found in the following section.

Respiratory services. Services per capita for respiratory diseases and symptoms were the third most frequent, accounting for 9.6 percent of all services. The U.S. average number of services per capita was 3.1 in 2012. Ohio had the largest number at 4.4, and Wyoming had the smallest number at 2.0.

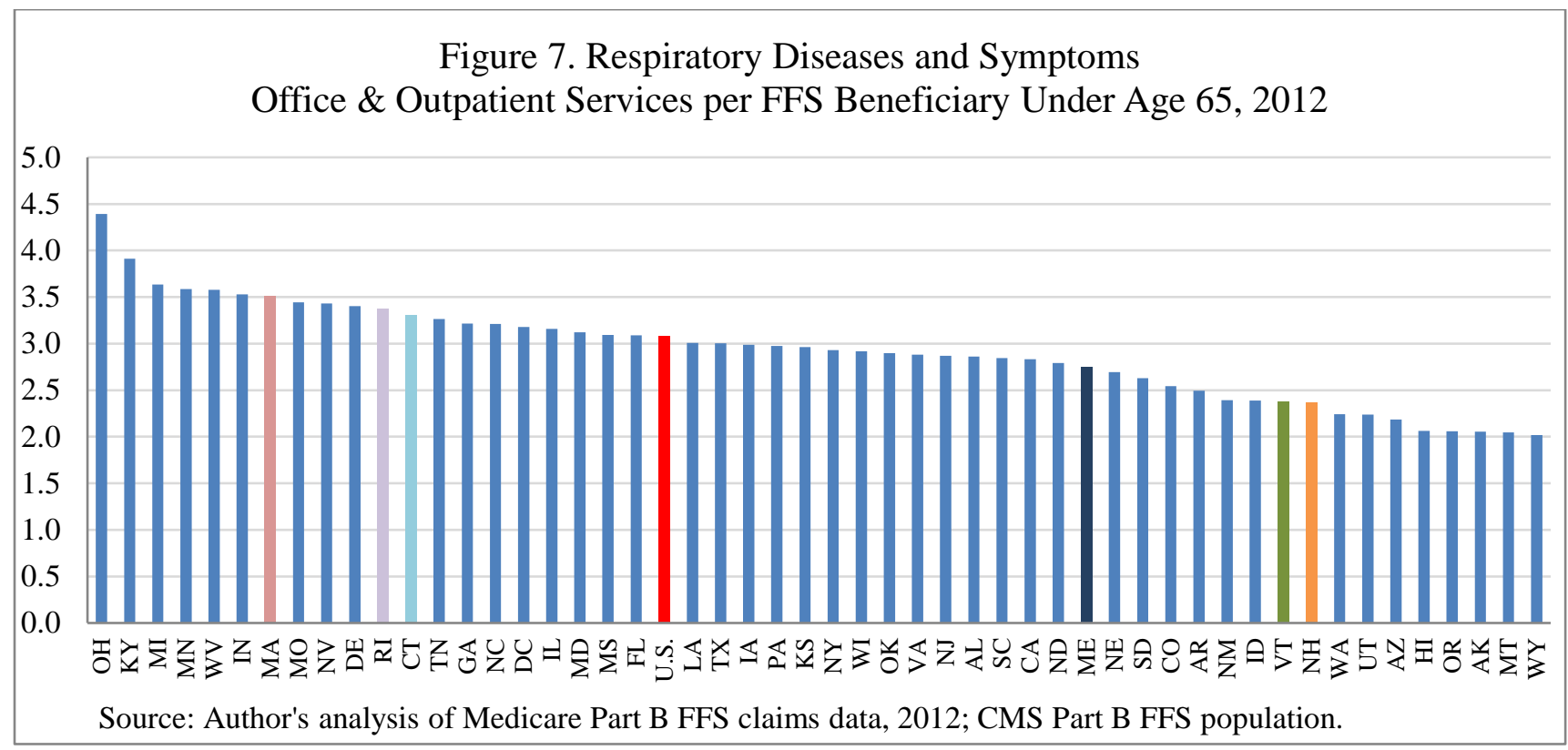

Circulatory services. Services per capita for circulatory diseases and symptoms were the fourth most frequent, accounting for 8.6 percent of all services. The U.S. average number of services per capita was 2.8 in 2012. Michigan had the largest number at 3.6 and Montana the smallest number at 1.4. 


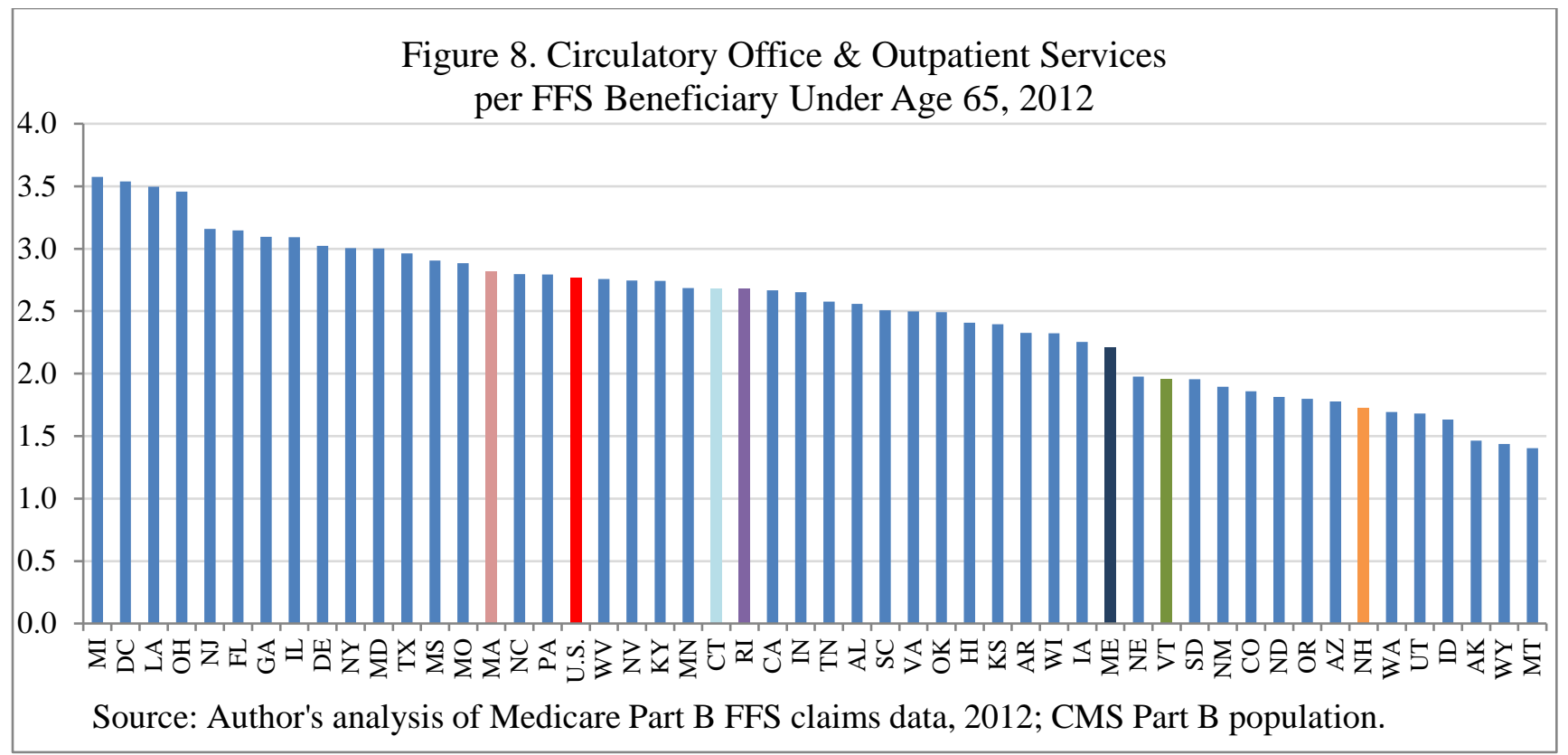

Endocrine services. Endocrine, nutritional and metabolic diseases and symptoms and immunity disorders including diabetes account for 8.0 percent of services, the fifth largest category. The U.S. average number of services per capita was 2.6 in 2012. Minnesota had the highest number at 3.5 services per capita, and Wyoming had the lowest number at 1.6 services per capita.

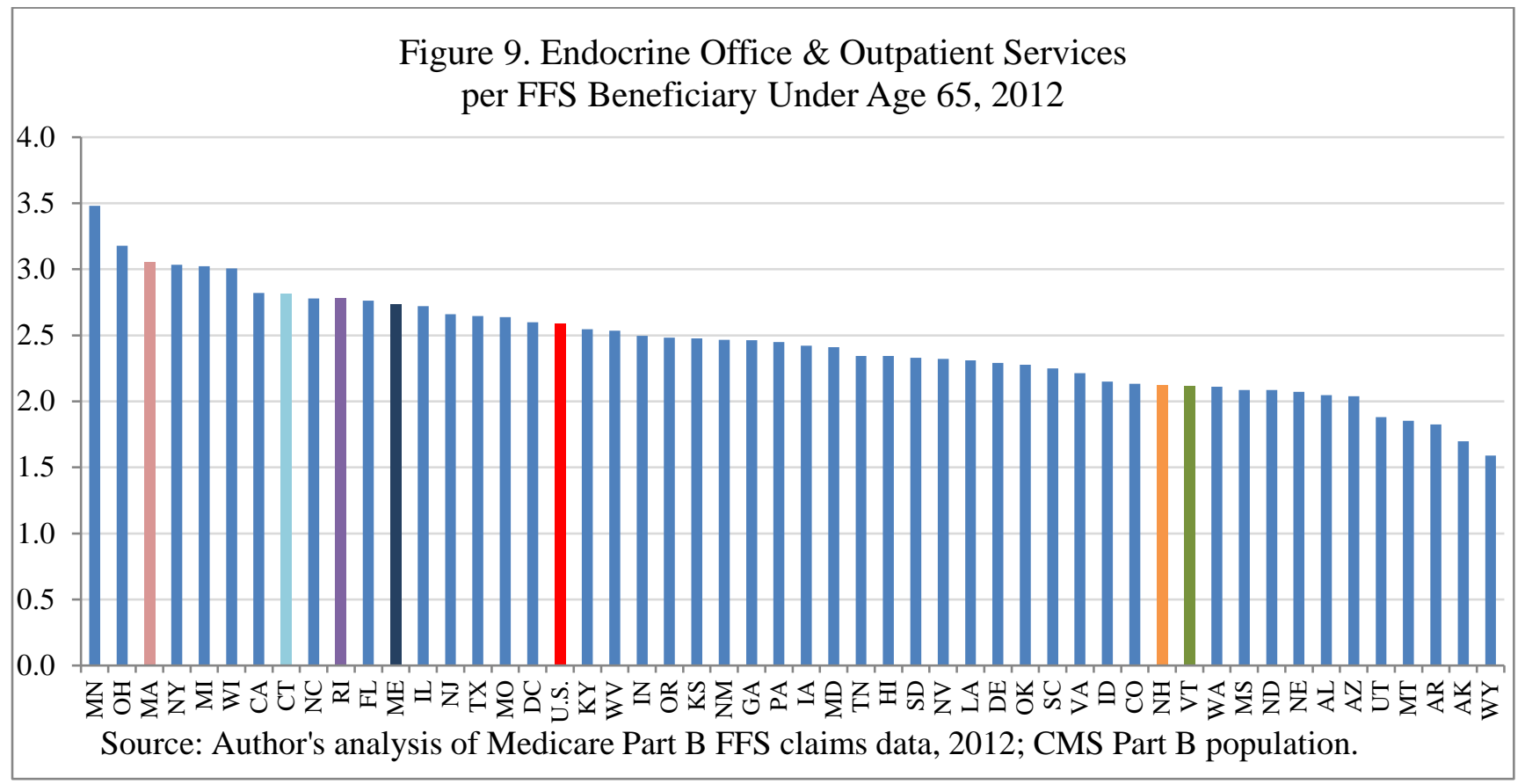




\section{B. Factors Associated with Cross-State Variation in Office and Outpatient Services}

To understand some of the factors associated with variation in per capita office and outpatient services for Medicare Part B FFS beneficiaries across states, I use log-log regression analysis. The dependent variable is the natural log of the number of services in a particular state in 2012 divided by the number of Medicare FFS enrollees under age 65 in that state. Right-hand-side variables reflect both the supply of health care from the provider community and characteristics of the population that influence the demand for health care from the SSDI population with FFS Medicare Part B. A short discussion of the variables appears below, and the regression statistics appear in Table 3. Sources for the right-hand-side variables appear in Appendix Table B1.

In addition to variables commonly used, I use a few others. First, I include the share of Medicare Part B enrollees in Medicare Advantage (MA). MA attracts a somewhat healthier group of enrollees than FFS, meaning that we would expect a higher rate of services by FFS enrollees in states with higher shares of MA enrollees. Second, the opioids prescribing rate per 100 people is associated with various types of services. Lower prescribing rates for opioids are associated with more health care services for several of the major diagnoses types, perhaps because some methods for pain management that replace or reduce opioid use require more health care services. Third, a measure of solar radiation in December for each state may indicate the general need of humans to enjoy sunlight; I find that states with more solar radiation tend to have fewer services for musculoskeletal and mental disorders.

All Services. Several factors are associated with total per capita office and outpatient services in each state: the share of MA enrollees under age 65 has a positive and significant association as does the number of health care professionals per 10,000 residents in each state. For each one percent increase in the MA share, the number of services per capita goes up 0.05 percent. For each one percent increase in health care professionals per 10,000 residents, the office and outpatient services per capita increase 0.84 percent. The number of community hospital beds per 1,000 residents has a negative and significant association; for each one percent increase in hospital beds per 1,000, office and outpatient services per capita go down by 0.25 percent. The opioid prescribing rate has a negative but insignificant effect on total services per capita. 
Musculoskeletal Services. Per capita musculoskeletal services in each state are associated with the MA share and a few demand-side variables. Factors with a positive and significant effect on musculoskeletal services include not only the share of MA enrollees but also the share of residents who live outside an urban area. For each one percent increase in the share of non-urban residents, the number of musculoskeletal services rises 0.03 percent. A measure of solar radiation in each state has a negative and significant effect. For every one percent increase in the measure of solar radiation, per capita services go down 0.16 percent. Neither the number of health care professionals per 10,000 nor the opioid prescribing rate has a significant influence.

Services for Mental Disorders. A broader set of factors is associated with services for mental disorders. Factors with a positive and significant effect include:

- Share of enrollees in Medicare Advantage

- Number of health care professionals per 10,000 residents

- $\quad$ Share of SSDI beneficiaries under age 50

- Dummy variable equal to one if a state does not implement Kendra’s Law; Kendra’s law mandates that people who have serious mental disorder issues and are a danger to themselves or others must regularly undergo psychiatric treatment.

Factors with a negative and significant effect on mental disorder services include:

- Share of residents incarcerated per 1,000 residents

- A measure of solar radiation

- $\quad$ The prescribing rate for opioids per 100 residents

Note that the state share of SSDI beneficiaries with mental impairments as the primary diagnosis is not associated with the number of services for mental conditions after controlling for the share of SSDI beneficiaries under age 50. The role of the incarceration rate is worth a mention as well. Because a large share of inmates have psychiatric conditions but are not eligible to receive SSDI or Medicare benefits, a higher rate of incarceration removes people with mental disorders from the SSDI and Medicare populations, thereby reducing the number of services needed for mental disorders.

Finding a negative relationship between the opioid prescription rate and the number of services for mental disorders may seem counterintuitive. Krueger (2017) recently found that higher rates 
of opioid prescriptions by county were associated with higher percentages of prime age men and women (ages 25 to 54) not in the labor force. Moreover, he estimated that between 25 percent and 35 percent of men who were not in the labor force were SSDI beneficiaries. Logic seems to suggest that more opioids lead to more people on the SSDI program who need medical assistance. However, I am looking at people who were already on the SSDI program in 2010 or earlier and who were managing their chronic pain or substance abuse issue in 2012. Health care providers who treated chronic pain and/or substance abuse by prescribing more drugs may have reduced the need for those patients to see health care providers more frequently. On the other hand, health care providers with lower prescribing rates may have encouraged other treatments such as relaxation therapies, cutaneous stimulation, guided imagery, hypnosis, or biofeedback that involve behavioral or physical therapists. As a result, higher opioid prescribing rates may have been associated with more people on the SSDI program but fewer health care services for those already on the program.

Respiratory Services. Respiratory services include services for both respiratory diseases and symptoms. Factors with a positive, significant effect include the share of MA enrollees and the number of health care professionals per 10,000 residents. The prescribing rate for opioids per 100 residents and the share of the population that smokes have insignificant effects on services.

Circulatory Services. Office and outpatient services for circulatory diagnoses or symptoms are positively associated with the share of MA enrollees, the share of African-Americans in the population, and the number of health care professionals per 10,000 residents. The share in nonurban environments and the prescribing rate for opioids have insignificant effects.

Endocrine Services. The share of MA enrollees and the number of health care providers per 10,000 residents are positively and significantly associated with services for endocrine diseases. Higher opioid prescribing rates per 100 residents are associated with fewer office and outpatient endocrine services. Some portion of the endocrine services likely reflects the needs of end-stage renal disease (ESRD) patients rather than non-ESRD SSDI beneficiaries, but the data do not allow us to differentiate between the two groups. 
Table 2. Factors Associated with the Cross-State Variation in Health Care Services

\begin{tabular}{|c|c|c|c|c|c|c|c|}
\hline & & \multicolumn{6}{|c|}{$\begin{array}{c}\text { Effect on Office and Outpatient FFS Services per FFS Enrollee } \\
\text { Under Age 65; } \\
\text { t-Statistics in Parentheses }\end{array}$} \\
\hline & & Total & $\begin{array}{c}\text { Musculo- } \\
\text { skeletal }\end{array}$ & $\begin{array}{c}\text { Mental } \\
\text { Disorders }\end{array}$ & $\begin{array}{l}\text { Respira- } \\
\text { tory }\end{array}$ & $\begin{array}{l}\text { Circula- } \\
\text { tory }\end{array}$ & Endocrine \\
\hline & $\begin{array}{l}\text { Adjusted } \\
\text { R-squared }\end{array}$ & 0.49 & 0.21 & 0.77 & 0.30 & 0.73 & 0.42 \\
\hline 1 & $\begin{array}{l}\text { Share of Part B } \\
\text { enrollees in } \\
\text { Medicare } \\
\text { Advantage }\end{array}$ & $\begin{array}{l}0.05 \\
(2.3)\end{array}$ & $\begin{array}{l}0.06 \\
(1.9)\end{array}$ & $\begin{array}{l}0.12 \\
(2.4)\end{array}$ & $\begin{array}{l}0.08 \\
(2.1)\end{array}$ & $\begin{array}{l}0.08 \\
(3.3)\end{array}$ & $0.12(5.2)$ \\
\hline 2 & $\begin{array}{l}\text { \% DI Population } \\
\text { under Age } 50\end{array}$ & & & $\begin{array}{l}1.65 \\
(3.4)\end{array}$ & & & \\
\hline 3 & $\begin{array}{l}\text { \% Population } \\
\text { Who Smoke }\end{array}$ & & & & $\begin{array}{l}0.15 \\
(0.7)\end{array}$ & & \\
\hline 4 & $\begin{array}{l}\text { \% Population } \\
\text { African- } \\
\text { American }\end{array}$ & & & & & $\begin{array}{l}0.18 \\
(1.5)\end{array}$ & \\
\hline 5 & $\begin{array}{l}\text { \% Population } \\
\text { not Urban }\end{array}$ & & $\begin{array}{l}0.03 \\
(2.5)\end{array}$ & & & $\begin{array}{l}0.01 \\
(0.5)\end{array}$ & \\
\hline 6 & $\begin{array}{l}\% \text { Incarcerated } \\
\text { per } 1,000\end{array}$ & & & $\begin{array}{l}-0.24 \\
(-1.7)\end{array}$ & & & \\
\hline 7 & $\begin{array}{l}\text { Solar Radiation } \\
\text { in December }\end{array}$ & & $\begin{array}{l}-0.16 \\
(-2.5)\end{array}$ & $\begin{array}{l}-0.19 \\
(-2.0)\end{array}$ & & & \\
\hline 8 & $\begin{array}{l}\text { \# Healthcare } \\
\text { Professionals per } \\
10,000\end{array}$ & $\begin{array}{l}0.84 \\
(6.5)\end{array}$ & $\begin{array}{l}0.21 \\
(1.5)\end{array}$ & $\begin{array}{l}0.82 \\
(3.5)\end{array}$ & $\begin{array}{l}0.57 \\
(3.3)\end{array}$ & $\begin{array}{l}0.37 \\
(3.0)\end{array}$ & $\begin{array}{l}0.45 \\
(4.1)\end{array}$ \\
\hline 9 & $\begin{array}{l}\text { \# Community } \\
\text { Hospital Beds } \\
\text { per } 1,000\end{array}$ & $\begin{array}{l}-0.25 \\
(-3.1)\end{array}$ & & & & & \\
\hline 10 & $\begin{array}{l}\text { Opioid Rx Rate } \\
\text { per } 100\end{array}$ & $\begin{array}{l}-0.06 \\
(-0.8)\end{array}$ & $\begin{array}{l}0.05 \\
(0.5)\end{array}$ & $\begin{array}{l}-0.49 \\
(-3.2)\end{array}$ & $\begin{array}{l}0.22 \\
(1.3)\end{array}$ & $\begin{array}{l}-0.07 \\
(-0.8)\end{array}$ & $\begin{array}{l}-0.12 \\
(-1.6)\end{array}$ \\
\hline 11 & $\begin{array}{l}\text { Dummy for no } \\
\text { Kendra's Law }\end{array}$ & & & $\begin{array}{l}0.27 \\
(2.5)\end{array}$ & & & \\
\hline
\end{tabular}

Source: Author's analysis; see Appendix B for sources of the various factors.

Having identified factors associated with the number of office and outpatient services per capita, we can compare the states with the highest number of services per capita in the Medicare data with the conditional number of services per capita after controlling for the factors identified above (see Table 3). Some states have higher services per capita both before and after controlling for those factors. For example, Vermont has higher numbers of total services per capita both before and after controlling for the factors identified. Michigan and Maine have higher numbers 
of musculoskeletal services per capita both before and after controlling for the factors identified. Massachusetts has higher numbers of mental disorder services per capita in both cases. Either the health care protocols offered in those states are significantly different from those in most states, or some other factor not yet identified could help to explain why those states have higher numbers of services per capita even after controlling for a number of factors.

Table 3. States with High Numbers of Services per FFS Beneficiary Under Age 65, In Medicare Data and After Controlling for Various Factors

\begin{tabular}{|c|c|c|c|c|c|c|}
\hline & Total & $\begin{array}{c}\text { Musculo- } \\
\text { skeletal }\end{array}$ & $\begin{array}{c}\text { Mental } \\
\text { Disorders }\end{array}$ & $\begin{array}{c}\text { Respira- } \\
\text { tory }\end{array}$ & $\begin{array}{c}\text { Circula- } \\
\text { tory }\end{array}$ & $\begin{array}{l}\text { Endo- } \\
\text { crine }\end{array}$ \\
\hline $\begin{array}{l}\text { States with large numbers of } \\
\text { office and outpatient services } \\
\text { per capita in Medicare data* }\end{array}$ & $\begin{array}{c}\text { MN, } \\
\text { MA, } \\
\text { VT, MI, } \\
\text { OH }\end{array}$ & $\begin{array}{l}\text { MN, MI, } \\
\text { DE, NV, } \\
\text { WI }\end{array}$ & $\begin{array}{l}\text { MA, } \\
\text { MN, CT, } \\
\text { ME, VT }\end{array}$ & $\begin{array}{c}\text { OH, } \\
\text { KY, MI, } \\
\text { MN, } \\
\text { WV }\end{array}$ & $\begin{array}{l}\text { MI, DC, } \\
\text { LA, OH, } \\
\quad \text { NJ }\end{array}$ & $\begin{array}{c}\text { AR, } \\
\text { WY, } \\
\text { PA, AK, } \\
\text { MT }\end{array}$ \\
\hline $\begin{array}{l}\text { States with large number of } \\
\text { services per capita after } \\
\text { controlling for various } \\
\text { factors* }\end{array}$ & $\begin{array}{l}\text { NV, } \\
\text { MN, } \\
\text { MI, VT, } \\
\text { CA }\end{array}$ & $\begin{array}{l}\text { NV, DE, } \\
\text { MN, FL, } \\
\quad \text { MI }\end{array}$ & $\begin{array}{l}\text { NV, IN, } \\
\text { FL, OK, } \\
\text { LA }\end{array}$ & $\begin{array}{l}\text { NV, } \\
\mathrm{MD}, \\
\mathrm{CA}, \\
\mathbf{O H}, \mathrm{IL}\end{array}$ & $\begin{array}{l}\text { WV, MI, } \\
\text { ME, NV, } \\
\quad \text { IL }\end{array}$ & $\begin{array}{l}\text { MI, CA, } \\
\text { IL, MN, } \\
\quad \mathrm{NC}\end{array}$ \\
\hline
\end{tabular}

*Note: States in bold have large numbers of services per capita in both analyses

\section{An Alternative Way to Allocate Services per FFS Beneficiary Under Age 65}

In the analysis described thus far, I have allocated services for any primary diagnosis to the entire population of Part B FFS enrollees under age 65 in each state. An alternative way to allocate services is to assign services with a major primary diagnosis type only to the share of Part B FFS enrollees under age 65 in the state corresponding to the share of SSDI enrollees with that primary diagnosis type at the time of eligibility. For example, 19.4 percent of SSDI beneficiaries in Massachusetts in 2010 were eligible on the basis of musculoskeletal conditions. If I assign all musculoskeletal services only to those SSDI beneficiaries, I find 22.4 musculoskeletal services per musculoskeletal beneficiary in 2012 (see Table 4). That number represents the maximum number of services, on average, for beneficiaries who were eligible on the basis of musculoskeletal conditions. Of course, other SSDI beneficiaries saw health care providers for musculoskeletal problems as well, and the measure is highly imprecise.

Nevertheless, it does recognize that the primary reason for eligibility may point to primary users of health care in a particular diagnosis group. 
The two major diagnosis groups examined in the alternative way represent more than three-fifths of the beneficiaries on the SSDI program: their primary diagnosis at the time of eligibility was either musculoskeletal conditions or mental disorders. In fact, given the low mortality rates of beneficiaries in those two groups, they represent an even greater share of the 2012 population of SSDI beneficiaries on Medicare. If all the musculoskeletal services in Massachusetts were used only by the share of SSDI beneficiaries who qualified at the time of eligibility on the basis of musculoskeletal conditions, those beneficiaries on average would have had 22.2 services over the year, almost every other week. In Hawaii, however, those musculoskeletal beneficiaries on average would have had 8.2 services over the year, or about one service every 6 weeks. For results on all states, see Appendix Figure C1.

If all the mental disorder services were used only by SSDI beneficiaries who qualified on the basis of mental disorders in the U.S. as a whole, those beneficiaries would have had 6.6 services on average in 2012, or slightly more than one service every two months. In Massachusetts in 2012, those beneficiaries would have had 14.6 services on average over the year, or more than 2 services per month. In Arizona, those mental disorders beneficiaries would have had an average of 2.4 services over the year, or one service every 5 months. For results on all states, see Appendix Figure C2.

Table 4. Services per FFS Beneficiary Under Age 65 Allocated in Two Ways, 2012

\begin{tabular}{|c|c|c|c|c|c|}
\hline & \multirow{2}{*}{$\begin{array}{l}\text { U.S. } \\
\text { Avg. }\end{array}$} & \multicolumn{2}{|c|}{ Highest state } & \multicolumn{2}{|c|}{ Lowest state } \\
\hline & & \# services & State & \# services & State \\
\hline \multicolumn{6}{|c|}{ If allocate services to all SSDI beneficiaries } \\
\hline Musculoskeletal & 4.6 & 6.7 & $\mathrm{MN}$ & 2.6 & HI \\
\hline Mental disorders & 3.2 & 9.1 & MA & 1.4 & $\mathrm{AL}$ \\
\hline \multicolumn{6}{|c|}{$\begin{array}{l}\text { If allocate services only to share of SSDI beneficiaries } \\
\text { with the same primary diagnosis }\end{array}$} \\
\hline Musculoskeletal & 18.1 & 35.7 & $\mathrm{MN}$ & 11.5 & $\mathrm{AR}$ \\
\hline Mental disorders & 9 & 17.9 & MA & 4.2 & MS \\
\hline
\end{tabular}

Source: Author's analysis of Medicare Part B FFS claims data, under age 65, 2012; CMS Part B FFS population; SSA Disability Insurance Program eligibility data 


\section{Discussion and Conclusion}

The wide variation in office and outpatient services by SSDI beneficiaries across states raises a number of questions about why beneficiaries in different parts of the country use health care differently. Even after recognizing various characteristics of each state’s population, selected characteristics of each state's SSDI population, and rough measures of the supply of health care in each state, differences remain. It is beyond the scope of this paper to identify whether states with higher or lower services per capita for mental disorders, for example, are using "best practices.” One way to address that issue might be to examine return-to-work statistics by state to discover any association between more or less health care support and the propensity to return to the labor force.

Of course, relying on health care alone to improve the lives and the employability of SSDI beneficiaries may not be the best strategy. For example, medical treatment of mental disorder outcomes in isolation can be expensive and inefficient (Alegria and Drake, 2017; Milstein, Briss, Burton, and Pechacek, 2011). A more holistic approach that includes community and workforce supports may be required to help people with disabilities overcome their challenges and integrate into the labor force.

An obvious question is whether the findings here for the Medicare Part B FFS population under age 65 would apply to the rest of the Medicare population, Medicaid enrollees, and people covered by private insurance. Some evidence of common treatment of all patients by health care providers does exist. Colla, et al. (2017) looked at the rates at which Medicare and private health plans provided seven low-value services and concluded that doctors tend to treat all patients similarly, regardless of who is paying the bill. They found that how much low-value care was offered was related to the history and organization of local health care markets, not the source of insurance. In particular, a higher ratio of specialists to primary care physicians led to higher provision of low-value services. Applying their findings to results in this paper suggests that states that stand out with higher or lower office and outpatient services per capita for the Medicare Part B population under age 65 may also provide more or less care in the form of services for the rest of the state's population, including others covered by Medicare, Medicaid, and private insurance. Further analysis of other data is needed to confirm that speculation. 


\section{$\underline{\text { References }}$}

Adams, Melissa L. and Gary J. Arminio. “Non-Pharmacologic Pain Management Intervention,” Clinics in Podiatric Medicine and Surgery 25, Issue 3 (2008): 409-429

Alegria, Margarita, Robert E. Drake, Hyeon-Ah Kang, Justin Metcalfe, Jingchen Liu, Karissa DiMarzio and Naomi Ali. "Simulations Test Impact of Education, Employment, And Income Improvements on Minority Patients with Mental Illness," Health Affairs 36, no.6 (2017):1024-1031; available at http://content.healthaffairs.org/content/36/6/1024.full.pdf

Autor, David and Mark Duggan. "The Rise in the Disability Rolls and the Decline in Employment.” Quarterly Journal of Economics, vol. 118 (2003):157-205.

Autor, David and Mark Duggan. "Supporting Work: A Proposal for Modernizing the US Disability Insurance System.” Washington, DC: Center for American Progress and The Hamilton Project, 2010.

Burkhauser, Richard and Mary Daly. "Social Security Disability Insurance: Time for a Fundamental Change.” Journal of Policy Analysis and Management, vol. 31 (2012):454-461.

Bye, B., G. Riley, and J. Lubitz. "Medicare Utilization by Disabled-Worker Beneficiaries: A Longitudinal Analysis,” Social Security Bulletin, vol. 50, no. 12(1987): 13-28. Available at https://www.ssa.gov/policy/docs/ssb/v50n12/v50n12p13.pdf.

Centers for Medicare \& Medicaid Services, Medicare \& Medicaid Statistical Supplement, Research Review/2013 Statistical Supplement, available at https://www.cms.gov/ResearchStatistics-Data-and-Systems/Statistics-Trends-andReports/MedicareMedicaidStatSupp/Downloads/2013_Section2.pdf

Centers for Medicare \& Medicaid Services, Interactive Atlas of Chronic Conditions, data for 2015; available at https://www.cms.gov/Research-Statistics-Data-and-Systems/StatisticsTrends-and-Reports/Chronic-Conditions/Interactive_Atlas.html

Chetty, Raj, Michael Stepner, Sarah Abraham, Shelby Lin, Benjamin Scuderi, Nicholas Turner, Augustin Bergeron, and David Cutler. "The Association between Income and Life Expectancy in the United States, 2001-2014.” Journal of the American Medical Association, April 2016, 1750-1766. Available at http://jamanetwork.com/journals/jama/fullarticle/2513561

Colla, C. H., Morden, N. E., Sequist, T. D., Mainor, A. J., Li, Z. and Rosenthal, M. B., "Payer Type and Low-Value Care: Comparing 'Choosing Wisely' Services across Commercial and Medicare Populations.” Health Services Research. (2017), doi:10.1111/1475-6773.12665

Cubanski, Juliette, Tricia Neuman, and Anthony Damico. "Medicare's Role for People Under Age 65 with Disabilities,” Kaiser Family Foundation (2016); available at 
http://www.kff.org/medicare/issue-brief/medicares-role-for-people-under-age-65-withdisabilities/

Cutler, David, Ellen Meara, and Susan Stewart. "Has Wider Availability of Prescription Drugs for Pain Relief Affected SSDI and SSI Enrollment?” presented at the Disability Research Consortium conference, August 2017; summary available at https://www.disabilitypolicyresearch.org/events/disability-research-consortium-annualmeeting-2017

Cutler, David, Jonathan Skinner, Ariel Dora Stern, and David Wennberg, "Physician Beliefs and Patient Preferences: A New Look at Regional Variation in Health Care Spending,” December 2017, forthcoming in American Economic Journal: Economic Policy.

Dartmouth Atlas of Health Care, Data by Topic, accessed on August 29, 2017 and available at http://www.dartmouthatlas.org/data/topic/.

Finkelstein, Amy, Matthew Gentzkow, and Heidi Williams. "Sources of Geographic Variation in Health Care: Evidence from Patient Migration.” The Quarterly Journal of Economics (2016), 1681-1726.

Krueger, Alan. "Where have all the workers gone? An inquiry into the decline of the U.S. labor force participation rate," presented as Brookings Paper on Economic Activity, September 7, 2017; available at https://www.brookings.edu/wp-content/uploads/2017/09/1_krueger.pdf

Liebman, J.B. "Understanding the Increase in Disability Insurance Benefit Receipt in the United States.” The Journal of Economic Perspectives, vol. 29 (2015):123-149.

Liu, Su, and David C. Stapleton. "Longitudinal Statistics on Work Activity and Use of Employment Supports for New Social Security Disability Insurance Beneficiaries.” Social Security Bulletin, vol. 71, no. 3 (2011):35-60.

Manchester, Joyce and Sam Tweed. "Why is the Prevalence of Young People on the Social Security Disability Program in Northern New England So High, And Why Has It Risen So Rapidly Since 2000?” Vermont Legislative Joint Fiscal Office Issue Brief, October 2015. http://www.leg.state.vt.us/jfo/issue_briefs_and_memos/SSDI_Prevalence_Issue_Brief.pdf

Milstein B, Homer J, Briss P, Burton D, Pechacek T. "Why behavioral and environmental interventions are needed to improve health at lower cost." Health Affairs (Millwood), vol. 30, no. 5(2011):823-32.

Railroad Retirement Board . "Medicare for Railroad Families,” April 2017; available at https://www.rrb.gov/sites/default/files/2017-05/QA1704.pdf.

Social Security Administration, Annual Statistical Report on the Disability Insurance Program, 2010. 
Trustees of the Old Age, Survivors and Disability Insurance Program. The 2018 OASDI Trustees Report. Baltimore, MD: Social Security Administration, 2018.

Von Wachter, Till, Jae Song, and Joyce Manchester. "Trends in Employment and Earnings of Allowed and Rejected Applicants to the Social Security Disability Insurance Program," American Economic Review, vol. 101, no. 7 (2011):3308-3329; available at http://www.econ.ucla.edu/tvwachter/papers/dissa_vwjsjm_final.pdf

Weathers, Robert R. II, Chris Silanskis, Michelle Stegman, John Jones, and Susan Kalasunas. "Expanding Access to Health Care for Social Security Disability Insurance Beneficiaries: Early Findings from the Accelerated Benefits Demonstration,” Social Security Bulletin, Vol. 70, No. 4, 2010; available at https://www.ssa.gov/policy/docs/ssb/v70n4/v70n4p25.html

Whitman, Kevin. "An Overview of the Railroad Retirement Program.” Social Security Bulletin 68, No. 2 (2008), Table 1; available at https://www.ssa.gov/policy/docs/ssb/v68n2/v68n2p41.html

Zayatz, Tim. "Social Security Disability Insurance Program Worker Experience,” Actuarial Study No. 123, August 2015, Table 13; available at https://www.ssa.gov/OACT/NOTES/pdf_studies/study123.pdf

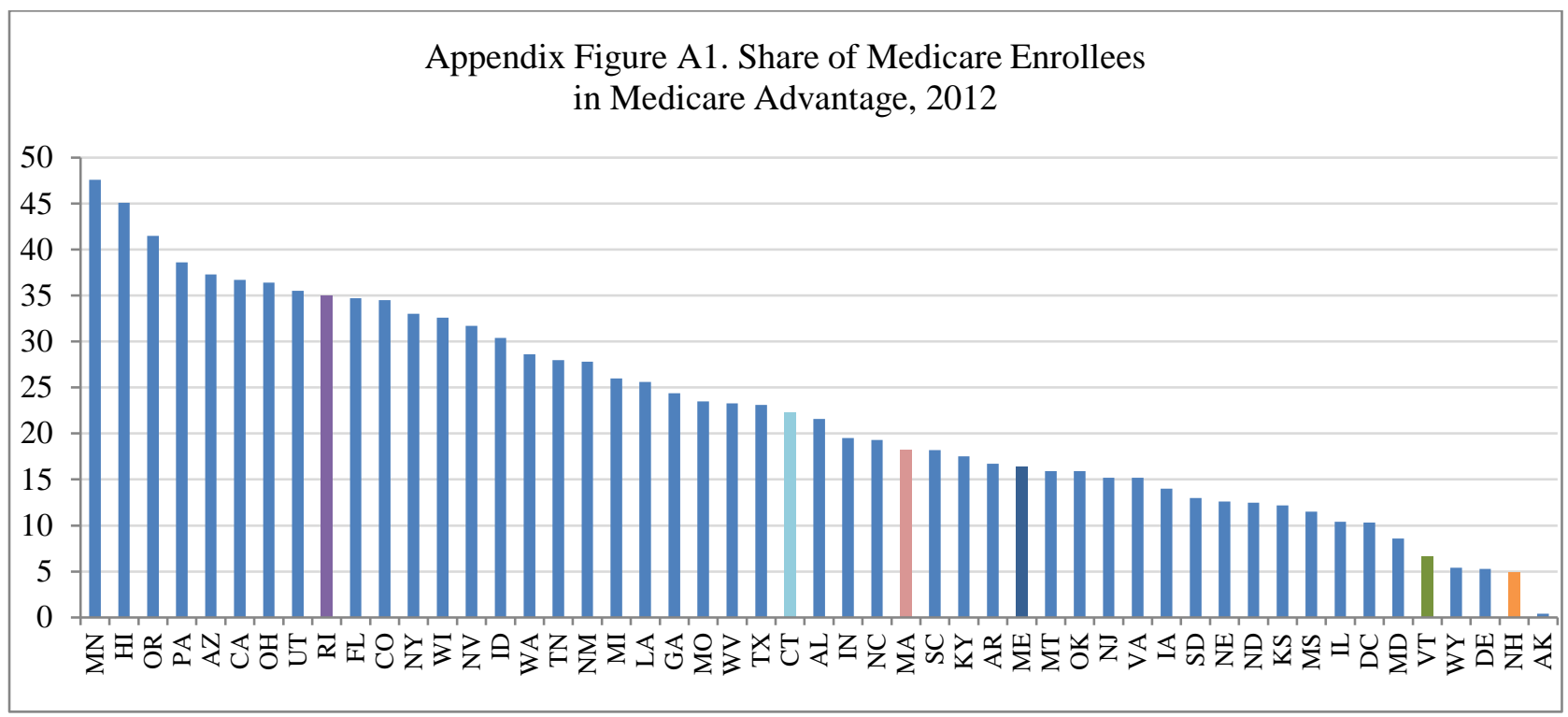


Appendix Table A1. Primary Reason for SSDI Eligibility, All Disabled Beneficiaries, December 2010

\begin{tabular}{|c|c|c|c|c|c|}
\hline & $\begin{array}{c}\text { Mood } \\
\text { disorders, } \\
\text { including } \\
\text { depression }\end{array}$ & & $\begin{array}{l}\text { Other, } \\
\text { including } \\
\text { anxiety } \\
\text { disorders }\end{array}$ & & $\begin{array}{l}\text { Schizo- } \\
\text { phrenic } \\
\text { and other } \\
\text { psychotic } \\
\text { disorders }\end{array}$ \\
\hline All areas & 14.3 & All areas & 3.8 & All areas & 5.5 \\
\hline Massachusetts & 22.6 & New Hampshire & 10.4 & District of Columbia & 11.7 \\
\hline New Hampshire & 22.4 & Maine & 9.7 & Hawaii & 9.9 \\
\hline Rhode Island & 20.5 & Vermont & 8.5 & Connecticut & 8.2 \\
\hline Minnesota & 18.5 & Massachusetts & 8.4 & Alaska & 8.0 \\
\hline Arizona & 17.9 & Rhode Island & 7.1 & California & 7.8 \\
\hline Vermont & 17.3 & Washington & 6.9 & New Jersey & 7.1 \\
\hline Connecticut & 17.1 & Hawaii & 6.7 & Massachusetts & 6.8 \\
\hline Maine & 17.1 & New Mexico & 6.5 & Utah & 6.6 \\
\hline Ohio & 16.9 & Idaho & 6.4 & Minnesota & 6.5 \\
\hline Hawaii & 16.5 & Montana & 6.4 & New York & 6.4 \\
\hline California & 16.3 & Oregon & 6.1 & Illinois & 6.3 \\
\hline Illinois & 15.7 & Wisconsin & 5.8 & North Dakota & 6.3 \\
\hline Kentucky & 15.2 & Alaska & 5.5 & Nebraska & 6.1 \\
\hline Michigan & 15.1 & Minnesota & 5.3 & Michigan & 6.0 \\
\hline Washington & 14.7 & Utah & 4.9 & Washington & 6.0 \\
\hline Tennessee & 14.6 & Wyoming & 4.9 & Maryland & 5.8 \\
\hline Texas & 14.6 & South Dakota & 4.6 & Ohio & 5.8 \\
\hline Idaho & 14.5 & Kansas & 4.5 & Wisconsin & 5.7 \\
\hline Pennsylvania & 14.0 & North Dakota & 4.5 & Florida & 5.6 \\
\hline New Mexico & 13.5 & Iowa & 4.4 & Rhode Island & 5.6 \\
\hline Florida & 13.3 & Kentucky & 4.4 & Iowa & 5.5 \\
\hline New Jersey & 13.3 & Colorado & 4.3 & Nevada & 5.5 \\
\hline Wisconsin & 13.3 & Ohio & 4.3 & Oregon & 5.5 \\
\hline Mississippi & 13.0 & Arizona & 4.2 & South Dakota & 5.5 \\
\hline Nevada & 13.0 & West Virginia & 4.2 & Colorado & 5.4 \\
\hline Utah & 12.9 & Nevada & 4.1 & Kansas & 5.3 \\
\hline Virginia & 12.8 & Indiana & 4.0 & Vermont & 5.3 \\
\hline District of Columbia & 12.7 & Nebraska & 4.0 & Arizona & 5.2 \\
\hline Indiana & 12.6 & Connecticut & 3.8 & Pennsylvania & 5.1 \\
\hline Maryland & 12.6 & Oklahoma & 3.8 & Indiana & 5.0 \\
\hline Oklahoma & 12.5 & Missouri & 3.6 & New Hampshire & 5.0 \\
\hline Colorado & 12.3 & New York & 3.6 & Georgia & 4.9 \\
\hline Kansas & 12.3 & California & 3.4 & Mississippi & 4.9 \\
\hline Delaware & 12.2 & Tennessee & 3.4 & Montana & 4.9 \\
\hline Missouri & 12.2 & Pennsylvania & 3.3 & Delaware & 4.8 \\
\hline New York & 11.8 & Texas & 3.3 & New Mexico & 4.8 \\
\hline Oregon & 11.6 & Arkansas & 3.2 & Virginia & 4.8 \\
\hline South Carolina & 11.6 & Illinois & 3.2 & Missouri & 4.7 \\
\hline Alabama & 11.4 & Michigan & 3.2 & Idaho & 4.5 \\
\hline Nebraska & 11.2 & North Carolina & 3.2 & Louisiana & 4.5 \\
\hline West Virginia & 11.2 & South Carolina & 3.2 & North Carolina & 4.5 \\
\hline Iowa & 11.0 & Virginia & 3.2 & Oklahoma & 4.5 \\
\hline
\end{tabular}




\begin{tabular}{llllll} 
Arkansas & 10.9 & Alabama & 3.1 & Wyoming & 4.5 \\
North Carolina & 10.8 & Delaware & 3.1 & Maine & 4.3 \\
Wyoming & 10.6 & New Jersey & 3.1 & South Carolina & 4.3 \\
Georgia & 10.5 & Mississippi & 2.9 & Texas & 4.3 \\
Alaska & 10.3 & Florida & 2.6 & Alabama & 4.1 \\
South Dakota & 10.2 & Georgia & 2.6 & Tennessee & 3.8 \\
Montana & 9.8 & Maryland & 2.4 & Arkansas & 3.7 \\
Louisiana & 9.5 & Louisiana & 2.3 & Kentucky & 2.9 \\
North Dakota & 9.2 & District of Columbia & 1.5 & West Virginia & 2.3 \\
\hline
\end{tabular}

Appendix Table B1. Sources of Right-Hand-Side Variables for Regressions

\begin{tabular}{|c|c|c|}
\hline 1 & $\begin{array}{l}\text { Share of Part B } \\
\text { Enrollees in Medicare } \\
\text { Advantage }\end{array}$ & $\begin{array}{l}\text { CMS, Office of Enterprise Data and Analytics, CMS Chronic } \\
\text { Conditions Data Warehouse. MDCR Enroll AB 7, } 2013 \text { adjusted }\end{array}$ \\
\hline 2 & $\begin{array}{l}\text { \% DI Population under } \\
\text { Age } 50\end{array}$ & $\begin{array}{l}\text { SSA, Annual Statistical Report on the Disability Insurance Program, } \\
\text { 2012. Table 27. Disabled Workers by Age and State }\end{array}$ \\
\hline 3 & $\begin{array}{l}\text { \% Population Who } \\
\text { Smoke }\end{array}$ & $\begin{array}{l}\text { Kaiser Family Foundation, Percent of Adults Who Smoke, 2013; Data } \\
\text { based on the Behavioral Risk Factor Surveillance System (BRFSS) }\end{array}$ \\
\hline 4 & $\begin{array}{l}\text { \% Population that is } \\
\text { African-American }\end{array}$ & U.S. Census, Decennial Census, 2010; as reported by Wikipedia \\
\hline 5 & \% Population not Urban & $\begin{array}{l}\text { U.S. Census Bureau, U.S. Decennial Census, 2010; } \quad(1 \text { - percentage of } \\
\text { the population that lives in urban areas) }\end{array}$ \\
\hline 6 & $\begin{array}{l}\text { Number Incarcerated per } \\
1,000 \text { Adults }\end{array}$ & $\begin{array}{l}\text { U.S. Bureau of Justice Statistics, "Correctional Populations in the } \\
\text { United States, 2013," reported per 100,000 adults by Wikipedia }\end{array}$ \\
\hline 7 & $\begin{array}{l}\text { Measure of Solar } \\
\text { Radiation in December }\end{array}$ & $\begin{array}{l}\text { The Solar Radiation Data Manual for Flat-Plate and Concentrating } \\
\text { Collectors, 1961-1990, state tables, use December, Tilt }=0\end{array}$ \\
\hline 8 & $\begin{array}{l}\text { \# Healthcare } \\
\text { Professionals per } 10,000\end{array}$ & $\begin{array}{l}\text { The Henry J. Kaiser Family Foundation, Total Health Care } \\
\text { Employment, data for 2015; U.S. Census, Population by State in } 2015\end{array}$ \\
\hline 9 & $\begin{array}{l}\text { \# Community Hospital } \\
\text { Beds per } 1,000\end{array}$ & $\begin{array}{l}\text { Staffed Community Hospital Beds per 1,000 Population by Ownership } \\
\text { Type, 2012; The Henry J. Kaiser Family Foundation }\end{array}$ \\
\hline 10 & $\begin{array}{l}\text { Opioid Prescribing Rate } \\
\text { per } 100\end{array}$ & $\begin{array}{l}\text { Prescribing rates per } 100 \text { persons, by state and drug type; IMS Health, } \\
\text { United States, } 2012\end{array}$ \\
\hline
\end{tabular}

Kendra's Law grants judges the authority to issue orders that require people who meet certain criteria to regularly undergo psychiatric

Dummy for no
Kendra's Law treatment. Four states do NOT impose Kendra's Law: CT, MD, MA, TN; See Treatment Advocacy Center, Assisted Outpatient Treatment Laws, available at http://www.treatmentadvocacycenter.org/component/content/article/39 

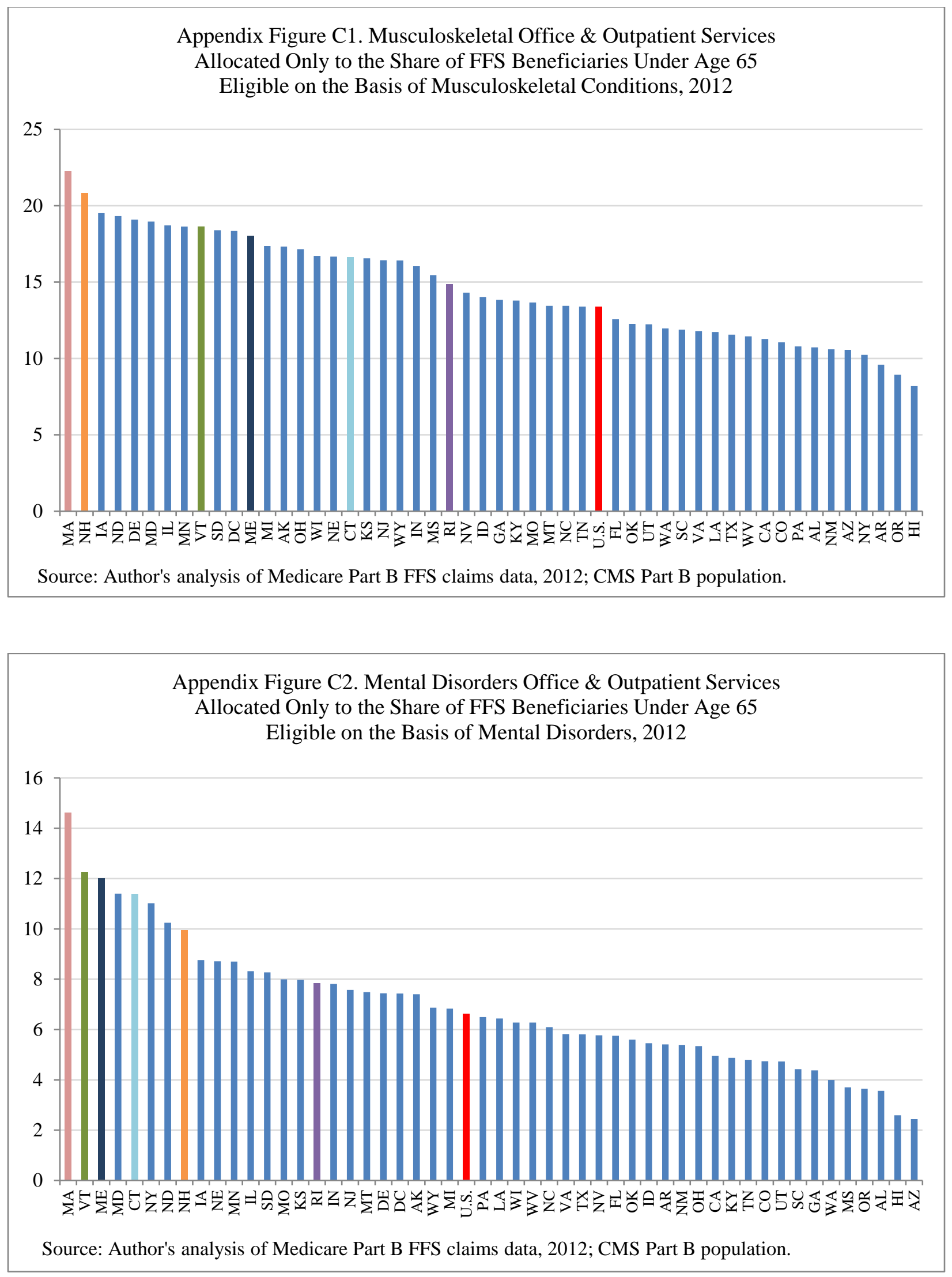